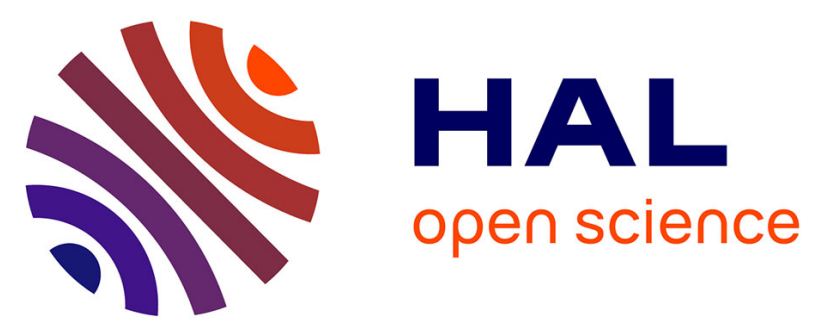

\title{
Activation of a nuclear localized-SIPK in tobacco cells challenged by cryptogein, an elicitor of plant defence reactions
}

Jennifer Dahan, Carole Pichereaux, Michel Rossignol, Sabrina Blanc, David Wendehenne, Alain Pugin, Stephane Bourque

\section{To cite this version:}

Jennifer Dahan, Carole Pichereaux, Michel Rossignol, Sabrina Blanc, David Wendehenne, et al.. Activation of a nuclear localized-SIPK in tobacco cells challenged by cryptogein, an elicitor of plant defence reactions. Biochemical Journal, 2009, 418 (1), pp.191-200. 10.1042/BJ20081465 . hal00479071

\section{HAL Id: hal-00479071 \\ https://hal.science/hal-00479071}

Submitted on 30 Apr 2010

HAL is a multi-disciplinary open access archive for the deposit and dissemination of scientific research documents, whether they are published or not. The documents may come from teaching and research institutions in France or abroad, or from public or private research centers.
L'archive ouverte pluridisciplinaire HAL, est destinée au dépôt et à la diffusion de documents scientifiques de niveau recherche, publiés ou non, émanant des établissements d'enseignement et de recherche français ou étrangers, des laboratoires publics ou privés. 


\section{1 \\ Activation of a nuclear localized-SIPK in tobacco cells challenged by cryptogein, an elicitor of plant defence reactions}

Jennifer Dahan ${ }^{*}$, , Carole Pichereaux $^{\dagger}$, Michel Rossignol ${ }^{\dagger}$, Sabrina Blanc ${ }^{*}$, David Wendehenne, ${ }^{*}$, Alain Pugin ${ }^{*}, \S$ and Stéphane Bourque ${ }^{*}, \S$

* UMR INRA 1088 / CNRS 5184 / Université de Bourgogne Plante-Microbe-Environnement, 17 Rue Sully, BP 86510, 21065 Dijon cédex, France

${ }^{\dagger}$ Plateforme de protéomique Toulouse Midi-Pyrénées, IPBS/IFR40, 205 route de narbonne, 31077 Toulouse, France

$\S$ GDR CNRS N²688 «Calcium et régulation de l'expression des gènes en contexte normal et pathologique»

Short title: Cryptogein promotes the nuclear SIPK activation in tobacco cells

Author for correspondence: bourque@dijon.inra.fr

Acknowledgements: We thank Annick Chiltz, Agnès Klinguer and Delphine Desqué for technical assistance. This work was supported by the Ministère de l'Education Nationale, de la Recherche et de la Technologie, and the Conseil Régional de Bourgogne. 


\section{SUMMARY}

2

When a plant cell is challenged by a well-defined stimulus, complex signal transduction pathways are activated to promote the modulation of specific sets of genes and in fine to develop adaptive responses. In this context, protein phosphorylation plays a fundamental role through the activation of multiple protein kinase families. While the involvement of protein kinases at the plasma membrane and cytosolic levels are now well documented, their nuclear counterparts are still poorly investigated. In the field of plant defense reactions, no known study has yet reported the activation of a nuclear protein kinase and / or its nuclear activity in plant cells, although some protein kinases, e.g. MAPK, are known to be translocated into the nucleus. In the present report we investigated the ability of cryptogein, a proteinaceous elicitor of tobacco defense reactions, to induce different nuclear protein kinase activities. We found that at least four nuclear protein kinases are activated in response to cryptogein treatment in a time-dependent manner, some of them exhibiting $\mathrm{Ca}^{2+}$-dependent activity. Our study focused on one 47-kDa protein kinase with a $\mathrm{Ca}^{2+}$-independent activity, closely related to the MAPK family. After purification and microsequencing, this protein kinase was formally identified as SIPK, a biotic and abiotic stress-activated MAPK of tobacco. We also showed that cytosolic activation of SIPK is not sufficient to promote a nuclear SIPK activity, the latter being correlated with cell death. In that way, this study provides evidences of a functional nuclear MAPK activity involved in response to an elicitor treatment. 


\section{INTRODUCTION}

2

Plant cells challenged by stimuli develop adaptive responses based on the modulation of the expression of specific sets of genes which activities are tightly controlled by signalling cascades. However, with the exception of transcription factors, little information is available regarding the signaling events operating in the nucleus [1]. Indeed, the possibility that this organit displays specific transduction processes has been poorly investigated. One of the most demonstrative studies highlighting the ability of the nucleus to perceive and to manage a specific response according to the applied stimulus came from Pauly et al [2]. Using isolated nuclei from Nicotiana tabacum BY2 cells expressing the nuclear calcium reporter aequorin, these authors showed that plant cell nuclei are able to generate their own calcium signals independently of the changes in calcium ion concentration occuring in the cytosol. These data point out the ability of nuclei to perceive extranuclear stimuli and to convert it into an appropriate nuclear response. A related and still poorly understood process concerns the molecular mechanisms linking cytosolic events and the modulation of nuclear gene expression. In other words, the question of how a specific signal is transmitted from the cytosol to the nucleus remains largely unanswered.

Protein phosphorylation/dephosphorylation is a major prototypic posttranslational modification regulating protein function [3]. Based on animal studies, it is commonly assumed that once activated, plant nuclear protein kinases (PK) could modulate the activity of target proteins including transcription factors leading, in fine, to the up- or down-regulation of gene expression. However, whereas various studies predict a nuclear localization for several PK based on primary sequence analysis (that is the presence of a nuclear localisation site; [4, 5]) and/or the nuclear localisation of overexpressed chimeric GFP-PK [6], the possibility that the activity of these PK is modulated within the nucleus as well as their putative translocation from the cytosol to the nucleus in physiological contexts have been examined in only few cases $[7,8]$.

Cryptogein is a $10 \mathrm{kDa}$ proteinaceous elicitor secreted by the oomycete Phytophthora cryptogea, an avirulent pathogen of tobacco. Upon application to tobacco leaves, cryptogein triggers the expression of defense-related genes, a hypersentive response (HR) and a systemic acquired resistance (SAR) against various pathogenic micro-organisms [9]. The molecular mechanisms underlying the effects of cryptogein have been mainly investigated using tobacco cell suspensions (for review see [10]). These studies highlight a key role for PK in transducing the cryptogein signal. Notably, Lecourieux-Ouaked et al [11] demonstrated that the elicitor induced within 5 minutes the phosphorylation of about 20 polypeptides, this process being partly controlled by a primary calcium influx across the plasma membrane. The identity of these polypeptides has not been reported. Cryptogein was also shown to trigger the activation of cytosolic MAPK (mitogen-activated protein kinases), including WIPK (woundinduced protein kinase), SIPK (salicylic acid-induced protein kinase) and Ntf4 [12-15] as well as the activation of a $42-\mathrm{kDa}$ PK operating downstream of anion effluxes [16]. Accordingly, PK inhibitors efficiently suppressed cryptogein-induced events including ion fluxes, reactive oxygen and nitrogen species production and gene expression (reviewed by $[10,13]$ ). A role for SIPK and WIPK in the elicitor-induced defense responses has been tentatively assigned. Zhang et al [15] reported that staurosporine and K-252a, two Ser/Thr kinase inhibitors that blocked WIPK activation, suppressed cell death, suggesting a role for WIPK in HR developpement. A similar role for SIPK was also postulated on the basis that the overexpression in tobacco plants of NtMEK2, a MAPK kinase (MAPKK) catalysing the phosphorylation and subsequent activation of different MAPK including SIPK, led to the developpement of spontaneous necrosis [17]. Complementary evidences were obtained by Liu et al [18] and Menke et al [38], who showed that WRKY1, a transcription factor involved in 
1 the control of cell death, was in vitro phosphorylated by SIPK. However, the conclusions 2 drawned from these experiments require attention. First, a main problem facing these studies 3 is the current lack of drugs capable of selectively acting on one specific PK. Second, the 4 hypothesis that NtMEK2 activates PK disctincts from SIPK also involved in HR should not 5 be ruled out. Finally, it should be mentioned that a recent study showed that NbSIPK, the 6 Nicotiana benthamiana homologue of SIPK is located in the nucleus [19]. In vitro analysis 7 indicated that NbSIPK might be upregulated by the upstream nuclear MAPKK NbMKK1 8 which mediates Phytophthora infestans INF1 elicitor-mediated HR and non-host resistance to 9 Pseudomonas cichorii. The demonstration that NbSIPK is indeed one of the downstream 10 targets of $\mathrm{NbMKK} 1$ and is activated at the nuclear level in this biological model remains to be 11 demonstrated.

In the present study, we analyzed the ability of cryptogein to trigger the activation of nuclear PK and partly adressed the question of the identity of these PK. We demonstrated that 14 cryptogein activates a set of different nuclear PK showing distinct kinetics of activation and biochemical properties in term of $\mathrm{Ca}^{2+}$-dependence. One of these PK was firmly identified as SIPK. Finally we provided arguments that the activation of SIPK at the nuclear level is correlated to cell death. 


\section{MATERIALS AND METHODS}

2

\section{Cell culture and treatment}

Nicotiana tabacum cv Xanthi cell suspensions were cultivated as previously described [20]. Briefly, cell suspensions were maintained in Chandler's medium [21] on a rotary shaker (150 $\mathrm{rpm}, 25^{\circ} \mathrm{C}$ ) under continuous light (photon flux rate $30-40 \mu \mathrm{mol} \mathrm{m} \mathrm{m}^{-2} \mathrm{~s}^{-1}$ ). Cells were maintained in the exponential phase and subcultured $1 \mathrm{~d}$ prior to utilization. Treatment of cell suspensions was carried out directly in the culture medium.

Cryptogein was purified as previously described [22], and prepared as a $100 \mu \mathrm{M}$ stock solution in water. Oligogalacturonates (degrees of polymerization from 25 to 30 ) were provided lyophilized by Goëmar S.A. (Roscoff, France) and resuspended in water. All chemicals were purchased from Sigma-Aldrich. Sorbitol, salicylic and butyric acid were prepared in water. Gadolinium chloride $\left(\mathrm{Gd}^{3+}\right)$ and carboxy-PTIO (cPTIO) were prepared as stock solution in water, except that carboxy-PTIO was dissolved extemporaneously; diphenylene-iodonium (DPI), glibenclamide, and cycloheximide were dissolved in DMSO. Chemicals used as inhibitors were added $10 \mathrm{~min}$ before elicitor treatment. When needed, equivalent volumes of DMSO or water were added to control cells to ensure that they did not interfere with the experiments. Final DMSO concentration did not exceed $0.25 \%(\mathrm{v} / \mathrm{v})$. At various times, 30 to $40-\mathrm{mL}$ cells (typically $8-10 \mathrm{~g}$ fresh weight) were harvested by filtration, quickly frozen in nitrogen liquid and stored at $-80{ }^{\circ} \mathrm{C}$ until use.

\section{Preparation of nuclear extracts}

All steps were performed on ice and centrifugations were done at $4{ }^{\circ} \mathrm{C}$. Cell samples were ground in liquid nitrogen and thawed in 2 volumes of nucleus extraction buffer (NB1; Tris-Mes 25 mM, pH 7.5, hexylene-glycol 0.5 M, EDTA 5 mM, EGTA 5 mM, DTT 10 mM, $\mathrm{NaF} 10 \mathrm{mM}, \mathrm{Na}_{3} \mathrm{VO}_{4} 1 \mathrm{mM}, \beta$-glycerophosphate $50 \mathrm{mM}$, PMSF $1 \mathrm{mM}$ ). The suspensions were filtered through a nylon mesh with a porosity of $31 \mu \mathrm{m}$ (Sefar AG, Heiden), and the filtrate was centrifuged at $500 \mathrm{~g}$ for $10 \mathrm{~min}$. An aliquot $(500 \mu \mathrm{L})$ of the supernatant was centrifuged at $21,000 \mathrm{~g}$ for clarification and kept as a "cytosolic fraction". The initial pellet was resuspended in $10 \mathrm{~mL}$ of NB1 and this suspension was layered on top of a $3 \mathrm{~mL}$ layer of $25 \%$ iodixanol (Optiprep via AbCys S.A., Paris) in NB1, and centrifuged at $3,000 \mathrm{~g}$ for 30 min. The pellet was then washed by centrifugation at $300 \mathrm{~g}$ for $10 \mathrm{~min}$ in $15 \mathrm{~mL}$ of NB2 buffer (NB1 without hexylene-glycol). After discarding the supernatant, the pelleted nuclei were frozen in liquid nitrogen and stored at $-80^{\circ} \mathrm{C}$ until use. Nucleus integrity was checked by fluorescent microscopy using a double coloration with propidium iodide and $\operatorname{DIOC}_{6}(3)$ as an endoplasmic reticulum dye. Nuclear-enriched fractions contamination rate was estimated by measuring the activity of marker enzymes [23-25].

\section{In-gel kinase activity assays}

Nuclear proteins analyzed by electrophoresis were extracted using the TriReagent (Molecular Research Center, Inc), following the instructions of the manufacturer. The nuclear proteins were resuspended in an urea buffer ( $7 \mathrm{M}$ urea, $2 \mathrm{M}$ thiourea, $4 \%$ CHAPS (w/v), $10 \mathrm{mM}$ DTT) and diluted with at least 2 volumes of Laemmli buffer for in-gel kinase assays or western blot experiments. In-gel kinase assays were performed as described previously [14] using $20 \mu \mathrm{g}$ of nuclear proteins. Separating SDS-polyacrylamide gels were embedded with a PK substrate, i.e. histone-IIIS $\left(0.14 \mathrm{mg} \cdot \mathrm{mL}^{-1}\right)$ or MBP $\left(0.12 \mathrm{mg} \cdot \mathrm{mL}^{-1}\right)$. Once the phosphorylation reaction was performed, the gels were dried onto Whatmann 3MM paper and exposed to Kodak XAR-5 films. Prestained size markers (Fermentas) were used to estimate the apparent molecular mass of the PK. 


\section{Immunoblot Analysis}

2

Nuclear and cytosolic proteins from control and cryptogein-treated cells were submitted to $10 \%$ SDS-PAGE and transferred to nitrocellulose membrane. The membrane was blocked for $2 \mathrm{hrs}$ at room temperature in TBST buffer $(10 \mathrm{mM}$ Tris, $\mathrm{pH} 7.5,100 \mathrm{mM}$ $\mathrm{NaCl}$, and $0.1 \%$ Tween 20 ) containing $1 \%$ bovine serum albumin (BSA), and then incubated overnight at $4{ }^{\circ} \mathrm{C}$ in the same buffer containing the primary antibodies anti-SIPK raised against the specific SIPK N-terminal peptide [14]. After incubation and several washings with TBST, the membrane was then incubated with the appropriate horseradish peroxydaseconjugated secondary antibodies (Bio-Rad). Detection was carried out using an ECL Western detection kit (Cell Signaling).

\section{Immunoprecipitation}

Nuclear proteins from untreated and cryptogein-treated cells were extracted by adding 2 volumes of lysis buffer (NB1 supplemented with $0.5 \mathrm{M} \mathrm{NaCl}, 0.5 \mathrm{MgCl}_{2}$ ) to the nuclei. After ultracentrifugation $(100000 \mathrm{~g}, 1 \mathrm{~h})$, immunoprecipitation using the nuclear proteins contained in the supernatant was carried out as previously described [26]. Immunoprecipitated proteins were analyzed by in-gel kinase assays using histone IIIS as substrate, in the presence of $\mathrm{Ca}^{2+}$.

\section{Purification of PK47 and mass spectrometry sequencing}

Nuclei obtained from $8 \mathrm{~kg}$ of tobacco cells were resuspended in $1 \mathrm{~L}$ of lysis buffer. After $60 \mathrm{~min}$ on ice, the suspension was ultracentrifuged at $100,000 \mathrm{~g}$ for $1 \mathrm{hr}$ at $4^{\circ} \mathrm{C}$. Using a $30-\mathrm{kDa}$ cut-off centricon, the extracted nuclear proteins were concentrated in the Q buffer (Tris-HCl $25 \mathrm{mM}$, EDTA $2 \mathrm{mM}$, EGTA $2 \mathrm{mM}$, $\beta$-glycerophosphate $50 \mathrm{mM}, \mathrm{MgCl}_{2} 25 \mathrm{mM}$, DTT $2 \mathrm{mM}$, glycerol $5 \%(\mathrm{v} / \mathrm{v})$, PMSF $1 \mathrm{mM}$ ) and were loaded onto a 5-mL Q-Sepharose anion exchange column (HiTrap Q HP column, Amersham BioSciences) equilibrated with the same Q buffer. After washing with $25 \mathrm{~mL}$ of buffer Q, the proteins were eluted with a $40-\mathrm{mL}$ linear gradient of 0 to $700 \mathrm{mM} \mathrm{NaCl}$ in buffer Q. The PK47 activity eluted with about 300 $\mathrm{mM} \mathrm{NaCl}$.

The fractions containing the highest PK47 activity, as determined by in-gel kinase assay using histone-IIIS as a substrate, were pooled and concentrated in buffer Q with 500 $\mathrm{mM} \mathrm{NaCl}$ and loaded onto a 1-mL hydrophobic interaction column (HiTrap phenyl-sepharose HP column, Amersham BioSciences) equilibrated in the same buffer. Bound proteins were eluted with a $20-\mathrm{mL}$ linear gradient of 0 to $60 \%$ ethylene-glycol and 500 to $0 \mathrm{mM} \mathrm{NaCl}$ in buffer Q. The PK47 active fractions (still determined using in-gel kinase assay with HIIIS as substrate) were then pooled and concentrated in buffer IP (HEPES-KOH $50 \mathrm{mM}, \mathrm{pH} 7.5$, EDTA $5 \mathrm{mM}$, EGTA $5 \mathrm{mM}, \mathrm{Na}_{3} \mathrm{VO}_{4} 1 \mathrm{mM}$, NaF $10 \mathrm{mM}, \beta$-glycerophosphate $50 \mathrm{mM}$, glycerol $5 \%(\mathrm{v} / \mathrm{v})$, PMSF $1 \mathrm{mM})$. The proteins were then incubated with $20 \mu \mathrm{g}$ of antibodies directed against SIPK and $85 \mu \mathrm{L}$ of packed volume of protein A-agarose beads (SigmaAldrich), at $4{ }^{\circ} \mathrm{C}$ for $12 \mathrm{~h}$ on a wheel. After washes, immunocomplexes were recovered in 30 $\mu \mathrm{L}$ of buffer IP added with $10 \mu \mathrm{L}$ of 5-fold concentrated Laemmli sample buffer, and were analyzed by $1 \mathrm{D}$-electrophoresis. The gel was stained using a mass spectrometry-compatible silver staining kit (Dodeca Silver Stain Kit, Bio-Rad). After 1D-electrophoresis, the PK47 corresponding band was excised and protein was characterized after trypsin in-gel digestion as previously described [27]. The trypsin digest was separated and analysed by nanoLCMS/MS using an Ultimate 3000 system (Dionex, Amsterdam, the Netherlands) coupled to an LTQ-Orbitrap mass spectrometer (Thermo Fisher Scientific, Bremen, Germany).

\section{Cell death}


Cell death was estimated as previously described [28] by using neutral red as a vital dye that accumulates in the acidic vacuole. Cells that did not accumulate neutral red were considered dead. Five hundred cells were counted for each treatment.

4

5 


\section{RESULTS}

2

\section{Cryptogein induces the activation of a set of nuclear protein kinases}

In order to investigate cryptogein-activated nuclear PK, we first set up an optimized protocol for the purification of nuclei from cultured tobacco cells. The extent of contamination by other cellular compartments including the cytosol, the endoplasmic reticulum, the Golgi apparatus and peroxysomes was followed by marker enzyme analysis. All of the marker enzymes assayed were poorly detectable in the nuclear preparation, the contamination rate being below $1 \%$ for each enzyme (Supplemental data 1 ). The integrity of the nuclei was ensured by the use of a detergent-free protocol [29] and controlled by the staining of enriched nuclei with DiOC6(3), an ER dye (data not shown). However, it should be specified that a significant contamination by cell wall fragments was observed (Supplemental data 2) and confirmed by ruthenium red and phloroglucinol staining of the nuclear preparations. But changes in buffer conditions, ionic strength or $\mathrm{pH}$ value did not significantly modify it. However the use of tobacco protoplasts as starting material was not conceivable since cryptogein does not induce any known signal transduction events (unpublished data).

To examine the putative involvement of nuclear PK in cryptogein signaling, tobacco cell suspensions were treated for various times with $100 \mathrm{nM}$ cryptogein and the corresponding nuclear protein extracts were analysed by in gel kinase assay using histone IIIS as a general phosphorylation substrate in presence of $0.5 \mathrm{mM} \mathrm{Ca}^{2+}$. As shown in Fig. 1A, several nuclear PK with molecular masses of 36, 55 and $60 \mathrm{kDa}$ (named PK36, PK55 and PK60, respectively) were constitutively activated in control cells. In nuclear protein extracts prepared from cryptogein-treated tobacco cells, 3 additional PK exhibiting a molecular mass of 42, 47 and $80 \mathrm{kDa}$ (named PK42, PK47 and PK80) were activated. Furthermore, the activity of the PK36, or of another PK with the same apparent molecular mass, was significantly increased following cryptogein treatment. A fifth PK with a molecular mass of $75 \mathrm{kDa}$ also showed a rise of activity in response to the elicitor. However, in contrast to PK36, PK42, PK47 and PK80, its activation was not systematically observed, as well as the enhanced activity of PK with the same molecular mass than the PK55 and PK60, detected in cryptogein-elicited cells.

In response to cryptogein, PK36, PK42, PK47 and PK80 displayed distinct kinetics of activation. PK36 activation was detected after $30 \mathrm{~min}$ of cryptogein treatment and lasted for $12 \mathrm{hrs}$; PK42 was slightly activated after 3 to $6 \mathrm{hrs}$, depending on the experiments, peaked at $9 \mathrm{hrs}$ and remained detectable up to $12 \mathrm{hrs}$ of treatment; PK47 was activated within 5 to 10 min following cryptogein application, and showed a high level of activity for at least $12 \mathrm{hrs}$; PK80 was activated after $30 \mathrm{~min}$ of cryptogein treatment and peaked at $3 \mathrm{hrs}$ before returning to basal level within 9 hrs (Fig. 1A).

To further characterize the biochemical features of the cryptogein-activated nuclear $\mathrm{PK}$, their $\mathrm{Ca}^{2+}$-dependence was assessed. For this purpose, nuclear proteins were analyzed by in-gel kinase assay using histone IIIS as substrate (a preferred one for CDPK) but without $\mathrm{Ca}^{2+}$ in the phosphorylation buffer (Fig. 1B). These conditions allow the detection of strictly $\mathrm{Ca}^{2+}$-independent PK activities. In the absence of $\mathrm{Ca}^{2+}$, only the activities of PK36, PK47 and PK60 were still detected. In contrast, the elicitor-triggered activation of PK42 and PK80 as well as the constitutive activity of PK55 were completely suppressed, highlighting the requirement of $\mathrm{Ca}^{2+}$ for their full activity. To confirm that theses PK activities were not due in part to cell wall contaminations, nuclear proteins were prepared after lysis of the nuclei by a high salinity buffer and ultracentrifugation to remove DNA, nuclear envelops and cell wall fragments. In these conditions we obtained the same PKs pattern (Fig. 1C), indicating that all PK activities described previously correspond to nuclear proteins. 
Taken together, these data highlight the ability of cryptogein to promote the activation

\section{Cryptogein activates a nuclear PK related to MAP kinases}

Amongst $\mathrm{Ca}^{2+}$-independent PK, MAPKs are the most studied PK involved in signalling pathway leading to defense responses. Based on the findings that cryptogein induces the activation of cytosolic MAPKs including WIPK, SIPK and Ntf4 [12-14] and that MAPKs are translocated into the nucleus upon activation in various mammalian transduction processes [30], we investigated whether some of the cryptogein-induced nuclear PK could correspond to MAPKs. Therefore, nuclear proteins were analyzed by in gel kinase assay using myelin basic protein (MBP), a preferential phosphorylation substrate compared to histone IIIS, in the absence of $\mathrm{Ca}^{2+}$ to favour the detection of $\mathrm{Ca}^{2+}$-independent MAPK activities [31]. As shown in Fig. 2, only the PK36, PK47 and PK60 were able to phosphorylate MBP, the PK47 and PK60 activities being more intense than those observed using histone IIIS as a substrate.

The PK47 displayed the same apparent molecular mass than SIPK [14]. We therefore investigated whether the PK47 activity could correspond to SIPK, or to a closely related PK. For this purpose, nuclear protein extracts from untreated and cryptogein-treated tobacco cell suspensions were immunodetected using a polyclonal antibody raised against SIPK [14]. As a control, the same experiment was carried out using cytosolic extracts. As expected, immunostaining revealed a reactive polypeptide of $47 \mathrm{kDa}$ in the cytosolic protein fractions, corresponding to SIPK (Fig. 3A). The immuno-reactive band was observed in both the control and cryptogein-treated cytosolic extracts, indicating that SIPK is constitutively produced as previously reported [13]. In the nuclear extracts, the antibodies detected a polypeptide with an apparent molecular mass of $47 \mathrm{kDa}$, suggesting that SIPK could be also present in the nuclei from both control and cryptogein-treated cells. However, we were unable to detect any significant accumulation of SIPK in the nucleus that could have suggested a translocation in response to cryptogein treatment. Intriguingly, in the nuclear fractions, besides the $47-\mathrm{kDa}$ polypeptide, a $45-\mathrm{kDa}$ polypeptide was also detected, this last one showing the most reactive signal, but the immuno-detection of the $\mathrm{P} 45$ was not reproducible.

To determine if the $47-\mathrm{kDa}$ polypeptide carries the PK47 activity, nuclear extracts from untreated and cryptogein-treated cells were immunoprecipitated with specific anti-SIPK polyclonal antibodies, and the resulting immunocomplexes were analyzed with the in-gel kinase assay technique using histone IIIS as a substrate and in the presence of $\mathrm{Ca}^{2+}$. These conditions were used because they allowed the detection of a higher number of nuclear PK activities as compared to MBP in the absence of $\mathrm{Ca}^{2+}$ (Fig. 1 versus Fig. 2). As shown in Fig. $3 \mathrm{~B}$, only the PK47 activity was clearly immunoprecipitated from the nuclear extracts of cryptogein-treated cells. No signal could be detected at $45 \mathrm{kDa}$, avoiding us to conclude on its putative activity, especially to determine whether it could correspond to an inactive form of SIPK. Work is in progress to identify P45. Therefore, this data strongly suggests that the nuclear PK47 corresponds to SIPK and although it is present both in control and cryptogeintreated cells, its activity is only observed in response to cryptogein treatment.

\section{Purification and identification of SIPK from nuclear protein-enriched extracts}

To confirm the assumption that the PK47 corresponds to SIPK, we undertook its purification from $70 \mathrm{mg}$ of nuclear proteins corresponding approximately to $8 \mathrm{~kg}$ of cryptogein-treated tobacco cells. The nuclear proteins were first loaded on a HiTrap Q anionic exchange column and each collected fraction was analyzed by in-gel kinase assay. As shown in Fig. 4A, several nuclear PK showing an induced activity in response to cryptogein, mainly the PK50-60, were eluted within the flowthrough. Other PK of interest, including the PK47, 
were retained by the column and subsequently eluted by increasing $\mathrm{NaCl}$ concentrations. The fractions containing the PK47 activity were pooled, loaded on a HiTrap Phenyl hydrophobic column and subsequently eluted with increasing concentrations of ethylene glycol and decreasing concentrations of $\mathrm{NaCl}$. The hydrophobic chromatography did not permit an efficient fractionation of the nuclear PK activities as most of them were collected both in the flowthrough and the eluted fractions (Fig. 4B). In contrast, activity of the P47 was specifically detected in eluted fractions. The corresponding fractions were pooled, desalted, concentrated and finally immunoprecipitated using the specific anti-SIPK polyclonal antibodies. The immunoreactive polypeptides were loaded on a preparative SDS-PAGE gel and the band corresponding to PK47 was excised for microsequencing (supplemental data 3 ).

The LC-MS/MS analysis of the tryptic digest from the immunopurified protein allowed the sequencing of four internal tryptic peptides, which unambiguously identified the PK47 protein as SIPK (Fig. 5). The predicted molecular mass of SIPK is $45.1 \mathrm{kDa}$ and calculated pI 5.53. Three of the sequenced peptides are shared with Ntf4, but the fourth ruled out the possibility that the purified PK47 could correspond to Ntf4. The MS/MS identification of SIPK from nuclear extracts confirmed the data obtained in immunoblot and immunoprecipitation experiments (Fig. 3), and demonstrated that SIPK is present and active in response to cryptogein in the nuclei of treated tobacco cells.

\section{Characterisation of the nuclear SIPK activation}

The cryptogein-induced signaling events acting upstream of cytosolic SIPK activation have been investigated in several studies. It was reported that SIPK activation is strictly dependent on the elicitor-triggered influx of extracellular $\mathrm{Ca}^{2+}$ [14]. In contrast, anion effluxes, NADPH oxidase-derived ROS and NO did not appear as essential components of the cryptogein-induced signaling pathway leading to the activation of SIPK [32]. To assess the involvement of signalling events in transmitting the cryptogein signal contributing to the activation of the nuclear SIPK, a pharmacological approach was performed.

The possible influence of the cryptogein-induced $\mathrm{Ca}^{2+}$ influx was investigated by blocking plasma membrane $\mathrm{Ca}^{2+}$ permeable channels using $\mathrm{Gd}^{3+}$. This compound has been shown to block the entrance of $\mathrm{Ca}^{2+}$ and subsequent $\mathrm{Ca}^{2+}$-dependent events in cryptogeintreated cells [33]. As shown in Fig. 6, $\mathrm{Gd}^{3+}$ completely suppressed nuclear SIPK activation. To determine a putative link between nuclear SIPK activation and cryptogein-induced anion effluxes, ROS and NO production, we next examined the effects of the plasma membrane anion channel inhibitors glibenclamide and niflumic acid (data not shown) [16], the NADPH oxidase inhibitor DPI [20] and the NO scavenger cPTIO [33]. These compounds had no inhibitory effects on the elicitor-triggered nuclear SIPK activation. Finally, the effect of cycloheximide, a widely-used inhibitor of protein synthesis, was also tested. Here too, cycloheximide did not impair the activation of the nuclear SIPK induced by cryptogein in cultured tobacco cells, suggesting that nuclear SIPK activation did not require prior de novo synthesis of SIPK itself or of other proteins acting upstream of its activation. This data fits well with those reported in the immunoblot (Fig. 3A) in which the amount of nuclear SIPK was comparable in both control and cryptogein-treated cells.

Together, these results indicate that SIPK is first regulated at the post-translational level in the cytosol and the nucleus and that similarly to its cytosolic counterpart, the activation of the nuclear SIPK is strictly dependent on the elicitor-trigger $\mathrm{Ca}^{2+}$ influx but independent of anion effluxes, ROS and NO production.

\section{Activation of SIPK by various stimuli}

Various stimuli, including biotic and abiotic stresses, activate cytosolic MAPK including SIPK [34]. However to our knowledge, no study analysed whether a cytosolic 
1 MAPK activation is paralleled by its activated form in the nucleus. We therefore investigated 2 the ability of stimuli known to trigger the activation of SIPK in the cytosol to promote an 3 active SIPK in the nucleus. Were tested as stimuli (i) oligogalacturonates (OGs), non-necrotic 4 elicitors of tobacco defence reactions [14]; ii) salicylic acid (SA, [35]); (iii) butyric acid (BA, 5 [26]); and (iv) hyperosmotic shock triggered by sorbitol [36]. As previously reported (see 6 above references), all these compounds provoked SIPK activation in the cytosolic extracts, 7 but with different kinetics (Fig. 7). OGs triggered a transient activation of SIPK, peaking at 10 $8 \mathrm{~min}$ and decreasing to basal levels within $60 \mathrm{~min}$. Sorbitol also produced a very transient activation of SIPK, which peaked at $5 \mathrm{~min}$ and disappeared within $30 \mathrm{~min}$. Similar data were obtained in response to SA but with a more extended kinetics. When used at $1 \mathrm{mM}$, BA used to acidify the cytosol [26] induced a slower activation of SIPK, occurring after $30 \mathrm{~min}$ of treatments and lasting for at least $2 \mathrm{hrs}$. Higher concentrations of BA (that is $5 \mathrm{mM}$ ) induced a faster, stronger and long-lasting activation which occurred within $5 \mathrm{~min}$ and was maintained for at least $2 \mathrm{hrs}$.

When the nuclear activity of SIPK was assessed, its activation was detected only in response to $5 \mathrm{mM} \mathrm{BA}$ (Fig. 7). In this condition, a slight activation occurred within $10 \mathrm{~min}$. The activation became stronger after $60 \mathrm{~min}$ where it reached a level of activation similar to those observed in response to cryptogein. Interestingly, in contrast to $250 \mathrm{mM}$ sorbitol, $1 \mathrm{mM}$ BA, SA and OGs, only cryptogein and $5 \mathrm{mM}$ BA triggered a significant cell death within 24 hrs, reaching $35 \%$ and $100 \%$, respectively.

Taken as a whole, these data indicate that the presence of the activated SIPK in the nucleus depends on the applied stimuli and is promoted by cell death-triggering signals. Furthermore, they suggest that the cytosolic activation of SIPK is not systematically paralleled by the presence of its activity in the nucleus, confirming that detection of active SIPK in the nucleus is not due to cytosolic contamination or mechanical translocation when cells are harvested. 


\section{DISCUSSION}

2

3

The possibility that nuclear PK could be specifically activated in plant cells challenged by biotic stresses has been suggested but not firmly established [8, 37, 38]. The data presented in this report support for the first time the conclusion that biotic stresses promote the activation of nuclear PK. Indeed, compared to control cells, at least four PK, that is PK36, PK42, PK47, and PK80, showed increased PK activities in nuclear protein extracts prepared from cryptogein-treated tobacco cells. Each PK was activated in a specific time-dependent manner, varying from min in the case of PK47 to several hours in the case of PK42. Several lines of evidence indicate that these activities did not reflect a contamination by cytosolic PK. G6PDH activity, a marker of the cytosolic and plastidic compartments [39], was extremely low in the nuclear fraction. An ambiguous situation came from the analysis of the activity of SIPK which was similarly detected in response to cryptogein treatment in both the cytosol and the nucleus. However, the observation that activated SIPK was specifically observed in cytosolic but not in nuclear extracts prepared from tobacco cells exposed to OGs, hyperosmotic stress, SA or $1 \mathrm{mM}$ BA provided further arguments ruling out the hypothesis that SIPK activity in the nuclear extracts could result from a cytosolic contamination.

The nuclear PK activated in response to cryptogein showed distinct biochemical features. PK activities of the PK50-55 and PK80 were strictly $\mathrm{Ca}^{2+}$-dependent, suggesting that those were probably due to CDPK or CCaMK [40]. Several representatives of these families have already been found to be located in the nuclear compartment. A study investigating the subcellular localization of several A. thaliana CDPK isoforms fused to GFP showed that at least two of them were constitutively nuclear [4]. A well-known CCaMK, DMI3, involved in nodulation in Medicago truncatula, also exhibits a nuclear localization when fused to GFP [41]. With the exception of nuclear CCaMK-like activities in response to temperature stress [42], the activities of such PK in the nuclear compartment has not yet been reported.

PK47 displayed features of MAPK including a comparable molecular mass and an efficiently phosphorylation activity toward MBP in a $\mathrm{Ca}^{2+}$-independent manner. Supporting this data, through combining immunological and biochemical purification approaches, we identified PK47 as the MAPK SIPK, providing the first evidence that MAPK are active within the nucleus of plant cells challenged with a biotic stress. Experiments with plasma membrane $\mathrm{Ca}^{2+}$ channel inhibitors indicate that $\mathrm{Ca}^{2+}$ influx from the extracellular space is required for nuclear SIPK activation in cryptogein-treated cells. In contrast, neither anion effluxes nor ROS and NO production appeared to be necessary for nuclear SIPK activation. Interestingly, such regulation resembles those already described for cytosolic SIPK [14, 16, 26]. By using various stimuli known to activate SIPK, our results also clearly demonstrated that the cytosolic activation of SIPK is a prerequisite but is not sufficient to induce the activity of the nuclear SIPK.

Taken together, these findings raise the question of whether SIPK nuclear activity results from the translocation of the activated cytosolic enzyme from the cytosol to the nucleus or whether it results from the direct activation of the nucleus enzyme. Results from the western blot analysis performed using antibodies raised against SIPK indicated that this PK is expressed both in the cytosol and in the nucleus of control and cryptogein-treated tobacco cells. Accordingly, using a chimeric SIPK-GFP construct under the control of the cauliflower mosaic virus 35S promoter, Menke et al [38] showed that SIPK is present both in the cytosol and the nucleus of tobacco BY2 cells. Similar results were obtained in Nicotiana benthamiana cells overexpressing a NbSIPK-GFP construct [19], but it was also shown in this case that a constitutively nuclear MAPKK, NbMKK1, interacts with and could be responsible for the nuclear activation of NbSIPK. However, both studies did not provide evidence that SIPK could be active at the nuclear level and/or translocated from the cytosol. Two hypothesis are conceivable to explain the activation of a nuclear localized SIPK: (i) SIPK is 
1 phosphorylated and activated in the cytosol by a MAPKK, presumably NtMEK2 [43], and 2 then translocated into the nucleus; (ii) SIPK could also be phosphorylated at the nuclear level 3 by a nuclear MAPKK, as suggested for NbMKK1, a nuclear MAPKK able to phosphorylate 4 in vitro NbSIPK [19]. In this case how his MAPKK could be activated in the nucleus remains undetermined. More generally, few studies have underlined the possibility that cytosolic MAPK could be translocated to the nucleus. For instance, in parsley cell suspensions, it was shown by immunolabelling that two MAPKs, PcMPK3 and PcMPK6 are translocated to the nucleus upon stimulation by the elicitor Pep13 [8]. Similarly, two A. thaliana MAPKs, AtMPK3 and AtMPK6, were shown to be translocated from the cytosol to the nucleus upon ozone treatment [37]. Here too, the demonstration that these MAPK are active in the nucleus has not been provided.

Although several studies point to the presence of plant MAPKs in the nucleus, their roles in this compartment have been poorly investigated to date. Indeed few substrates of these PK have been identified. Amongst those, WRKY1, the only known substrate for SIPK to date, was shown to be implicated in HR-like cell death in association with SIPK [38]. Similarly, Cheong et al [44] found that BWMK1, a rice nuclear MAPK, could activate by phosphorylation the transcription factor OsEREBP1 which could lead to PR-genes activation. More generally several transcription factors were evidenced to act downstream of MAPKs [45-49], accrediting the fact that the nuclear activity of SIPK we showed is related to the regulation of transcription. It is then of major importance to identify the putative nuclear targets of SIPK and the associated plant genes.

In summary, this work greatly extends previous studies describing the involvement of PK in plant defence by providing the first evidence of a functional nuclear MAPK activity involved in response to an elicitor treatment. Work in progress aims at investigating whether SIPK is directly activated within the nucleus or whether it is translocated from the cytosol to the nucleus in its activated form. 


\section{References:}

2

3

4

1 Eulgem, T. and Somssich, I. E. (2007) Networks of WRKY transcription factors in defense signaling. Curr. Opin. Plant Biol. 10, 366-371

2 Pauly, N., Knight, M. R., Thuleau, P., van der Luit, A. H., Moreau, M., Trewavas, A. J., Ranjeva, R. and Mazars, C. (2000) Cell signalling: control of free calcium in plant cell nuclei. Nature 405, 754-755

3 Ptacek, J. and Snyder, M. (2006) Charging it up: global analysis of protein phosphorylation. Trends Genet. 22, 545-554

4 Dammann, C., Ichida, A., Hong, B., Romanowsky, S. M., Hrabak, E. M., Harmon, A. C., Pickard, B. G. and Harper, J. F. (2003) Subcellular targeting of nine CalciumDependent Protein Kinase isoforms from arabidopsis. Plant Physiol. 132, 1840-1848

5 Raichaudhuri, A., Bhattacharyya, R., Chaudhuri, S., Chakrabarti, P. and DasGupta, M. (2006) Domain analysis of a groundnut Calcium-dependent Protein Kinase: nuclear localization sequence in the junction domain is coupled with nonconcensus calcium binding protein domains. J. Biol. Chem. 281, 10399-10409

6 Ishikawa, M., Soyano, T., Nishihama, R. and Machida, Y. (2002) The NPK1 mitogenactivated protein kinase kinase kinase contains a functional nuclear localization signal at the binding site for the NACK1 kinesin-like protein. Plant J. 32, 789-798

7 Ligterink, W., Kroj, T., Nieden, U. Z., Hirt, H. and Scheel, D. (1997) Receptormediated activation of a MAP kinase in pathogen defense of plants. Science 276, 2054-2057

8 Lee, J., Rudd, J. J., Macioszek, V. K. and Scheel, D. (2004) Dynamic changes in the localization of MAPK cascade components controlling Pathogenesis-related (PR) gene expression during innate immunity in parsley. J. Biol. Chem. 279, 22440-22448

9 Keller, H., Blein, J. P., Bonnet, P. and Ricci, P. (1996) Physiological and molecular characteristics of elicitin-induced systemic acquired resistance in tobacco. Plant Physiol. 110, 365-376

10 Garcia-Brugger, A., Lamotte, O., Vandelle, E., Bourque, S., Lecourieux, D., Poinssot, B., Wendehenne, D. and Pugin, A. (2006) Early signaling events induced by elicitors of plant defenses. Mol. Plant-Microbe Interact. 19, 711-724

11 Lecourieux-Ouaked, F., Pugin, A. and Lebrun-Garcia, A. (2000) Phosphoproteins involved in the signal transduction of cryptogein, an elicitor of defense reactions in tobacco. Mol. Plant-Microbe Interact. 13, 821-829

12 Ren, D., Yang, K.-Y., Li, G.-J., Liu, Y. and Zhang, S. (2006) Activation of Ntf4, a tobacco Mitogen-Activated Protein Kinase, during plant defense response and its involvement in hypersensitive response-like cell death. Plant Physiol. 141, 1482-1493

13 Zhang, S., Du, H. and Klessig, D. F. (1998) Activation of the tobacco SIP kinase by both a cell wall-derived carbohydrate elicitor and purified proteinaceous elicitins from Phytophthora spp. Plant Cell 10, 435-450

14 Lebrun-Garcia, A., Ouaked, F., Chiltz, A. and Pugin, A. (1998) Activation of MAPK homologues by elicitors in tobacco cells. Plant J. 15, 773-781

15 Zhang, S., Liu, T. and Klessig, D. (2000) Multiple levels of tobacco WIPK activation during the induction of cell death by fungal elicitins. Plant J. 23, 339-347

16 Wendehenne, D., Lamotte, O., Frachisse, J.-M., Barbier-Brygoo, H. and Pugin, A. (2002) Nitrate efflux is an essential component of the cryptogein signalling pathway leading to defense responses and hypersensitive cell death in tobacco. Plant Cell 14, 1937-1951 
17 Yang, K.-Y., Liu, Y. and Zhang, S. (2001) Activation of a mitogen-activated protein kinase pathway is involved in disease resistance in tobacco. Proc. Nat. Acad. Sci. USA 98, 741-746

18 Liu, Y., Schiff, M. and Dinesh-Kumar, S. P. (2004) Involvement of MEK1 MAPKK, NTF6 MAPK, WRKY/MYB transcription factors, COI1 and CTR1 in N-mediated resistance to tobacco mosaic virus. Plant J 38, 800-809

19 Takahashi, Y., Nasir, K. H. B., Ito, A., Kanzaki, H., Matsumura, H., Saitoh, H., Fujisawa, S., Kamoun, S. and Terauchi, R. (2007) A high-throughput screen of celldeath-inducing factors in Nicotiana benthamiana identifies a novel MAPKK that mediates INF1-induced cell death signaling and non-host resistance to Pseudomonas cichorii. Plant J. 49, 1030-1040

20 Pugin, A., Frachisse, J. M., Tavernier, E., Bligny, R., Gout, E., Douce, R. and Guern, J. (1997) Early events induced by the elicitor cryptogein in tobacco cells: involvement of a plasma membrane NADPH oxidase and activation of clycolysis and the pentose phosphate pathway. Plant Cell 9, 2077-2091

21 Chandler, M. T., Tandeau de Marsac, N. and De Kouchkovsky, Y. (1972) Photosynthetic growth of tobacco cells in liquid suspension. Can. J. Bot 50, 22652270

22 Bonnet, P., Bourdon, E., Ponchet, M., Blein, J. P. and Ricci, P. (1996) Acquired resistance triggered by elicitins in tobacco and others plants. Eur. J. Plant Pathol. 102, 181-192

23 Costa Rosa, L. F., Curi, R., Murphy, C. and Newsholme, P. (1995) Effect of adrenaline and phorbol myristate acetate or bacterial lipopolysaccharide on stimulation of pathways of macrophage glucose, glutamine and $\mathrm{O}_{2}$ metabolism. Evidence for cyclic AMP-dependent protein kinase mediated inhibition of glucose-6phosphate dehydrogenase and activation of $\mathrm{NADP}^{+}$-dependent 'malic' enzyme. Biochem. J. 310, 709-714

24 Kuzniak, E. and Sklodowska, M. (2004) Comparison of two methods for preparing mitochondria from tomato leaves to study the ascorbate-glutathione cycle activity. Biol. Plantarum 48, 537-542

25 Mitsui, T., Honma, M., Kondo, T., Hashimoto, N., Kimura, S. and Igaue, I. (1994) Structure and function of the Golgi complex in rice cells (II. Purification and characterization of Golgi membrane-bound nucleoside diphosphatase). Plant Physiol. 106, 119-125

26 Lebrun-Garcia, A., Chiltz, A., Gout, E., Bligny, R. and Pugin, A. (2002) Questioning the role of salicylic acid and cytosolic acidification in mitogen-activated protein kinase activation induced by cryptogein in tobacco cells. Planta 214, 792-797

27 Borderies, G., Jamet, E., Lafitte, C., Rossignol, M., Jauneau, A., Boudart, G., Monsarrat, B., Esquerré-Tugayé, M. T., Boudet, A. and Pont-Lezica, R. (2003) Proteomics of loosely bound cell wall proteins of Arabidopsis thaliana cell suspension cultures: a critical analysis. Electrophoresis 24, 3421-3432

28 Gauthier, A., Lamotte, O., Reboutier, D., Bouteau, F., Pugin, A. and Wendehenne, D. (2007) Cryptogein-induced anion effluxes: electrophysiological properties and analysis of the mechanisms through which they contribute to the elicitor-triggered cell death. Plant Signalling Behavior 2, 86-95

29 Xiong, T. C., Jauneau, A., Ranjeva, R. and Mazars, C. (2004) Isolated plant nuclei as mechanical and thermal sensors involved in calcium signalling. Plant J. 40, 12-21

30 Kondoh, K., Torii, S. and Nishida, E. (2005) Control of MAP kinase signaling to the nucleus. Chromosoma 114, 86-91 
31 Zhang, S. and Klessig, D. F. (1997) Salicylic acid activates a 48-kD MAP kinase in tobacco. Plant Cell 9, 809-824

32 Besson-Bard, A., Pugin, A. and Wendehenne, D. (2008) New insights into nitric oxide signaling in plants. Ann. Rev. Plant Biol. 59, 21-39

33 Lamotte, O., Gould, K., Lecourieux, D., Sequeira-Legrand, A., Lebrun-Garcia, A., Durner, J., Pugin, A. and Wendehenne, D. (2004) Analysis of nitric oxide signaling functions in tobacco cells challenged by the elicitor cryptogein. Plant Physiol. 135, 516-529

34 Mishra, N. S., Tuteja, R. and Tuteja, N. (2006) Signaling through MAP kinase networks in plants. Arch. Bioch. Biophys. 452, 55-68

35 Klessig, D. F., Durner, J. r., Noad, R., Navarre, D. A., Wendehenne, D., Kumar, D., Zhou, J. M., Shah, J., Zhang, S., Kachroo, P., Trifa, Y., Pontier, D., Lam, E. and Silva, H. (2000) Nitric oxide and salicylic acid signaling in plant defense. Proc. Nat. Acad. Sci. USA 97, 8849-8855

36 Mikolajczyk, M., Awotunde, O. S., Muszynska, G., Klessig, D. F. and Dobrowolska, G. (2000) Osmotic stress induces rapid activation of a salicylic acid-induced protein kinase and a homolog of protein kinase ASK1 in tobacco cells. Plant Cell 12, 165-178

37 Ahlfors, R., Macioszek, V., Rudd, J., Brosche, M., Schlichting, R., Scheel, D. and Kangasjarvi, J. (2004) Stress hormone-independent activation and nuclear translocation of mitogen-activated protein kinases in Arabidopsis thaliana during ozone exposure. Plant J. 40, 512-522

38 Menke, F. L. H., Kang, H.-G., Chen, Z., Park, J. M., Kumar, D. and Klessig, D. F. (2005) Tobacco transcription factor WRKY1 is phosphorylated by the MAP kinase SIPK and mediates HR-like cell death in tobacco. Mol. Plant-Microbe Interact. 18, 1027-1034

39 Kong, W.-F., Chen, J.-Y., Hou, Z.-X., Wen, P.-F., Zhan, J.-C., Pan, Q.-H. and Huang, W.-D. (2007) Activity and subcellular localization of glucose-6-phosphate dehydrogenase in peach fruits. J. Plant Physiol. 164, 934-944

40 Hrabak, E. M., Chan, C. W. M., Gribskov, M., Harper, J. F., Choi, J. H., Halford, N., Kudla, J., Luan, S., Nimmo, H. G., Sussman, M. R., Thomas, M., Walker-Simmons, K., Zhu, J.-K. and Harmon, A. C. (2003) The Arabidopsis CDPK-SnRK superfamily of protein kinases. Plant Physiol. 132, 666-680

41 Messinese, E., Mun, J.-H., Yeun, L. H., Jayaraman, D., Rouge, P., Barre, A., Lougnon, G., Schornack, S., Bono, J.-J., Cook, D. R. and Ane, J.-M. (2007) A novel nuclear protein interacts with the symbiotic DMI3 calcium- and calmodulin-dependent protein kinase of Medicago truncatula. Mol. Plant-Microbe Interact. 20, 912-921

42 Pandey, S., Tiwari, S. B., Tyagi, W., Reddy, M. K., Upadhyaya, K. C. and Sopory, S. $\mathrm{K}$. (2002) $\mathrm{A} \mathrm{Ca}^{2+} / \mathrm{CaM}-d e p e n d e n t$ kinase from pea is stress regulated and in vitro phosphorylates a protein that binds to AtCaM5 promoter. Eur. J. Biochem 269, 31933204

43 Liu, Y., Zhang, S. and Klessig, D. F. (2000) Molecular cloning and characterization of a Tobacco MAP kinase kinase that interacts with SIPK. Mol. Plant-Microbe Interact. 13, 118-124.

44 Cheong, Y. H., Moon, B. C., Kim, J. K., Kim, C. Y., Kim, M. C., Kim, I. H., Park, C. Y., Kim, J. C., Park, B. O., Koo, S. C., Yoon, H. W., Chung, W. S., Lim, C. O., Lee, S. Y. and Cho, M. J. (2003) BWMK1, a rice Mitogen-Activated Protein Kinase, locates in the nucleus and mediates Pathogenesis-Related gene expression by activation of a transcription factor. Plant Physiol. 132, 1961-1972 
45 Asai, T., Tena, G., Plotnikova, J., Willmann, M. R., Chiu, W.-L., Gomez-Gomez, L., Boller, T., Ausubel, F. M. and Sheen, J. (2002) MAP kinase signalling cascade in Arabidopsis innate immunity. Nature 415, 977-983

46 Ekengren, S. K., Liu, Y., Schiff, M., Dinesh-Kumar, S. P., and Martin, G. B. (2003) Two MAPK cascades, NPR1, and TGA transcription factors play a role in Ptomediated disease resistance in tomato. Plant J. 36, 905-917.

47 Liu, Y., Schiff, M. and Dinesh-Kumar, S. P. (2004) Involvement of MEK1 MAPKK, NTF6 MAPK, WRKY/MYB transcription factors, COI1 and CTR1 in $N$-mediated resistance to tobacco mosaic virus. Plant J. 38, 800-809

48 Kim, C. Y., and Zhang, S. (2004) Activation of a mitogen-activated protein kinase cascade induces WRKY family of transcription factors and defense genes in tobacco. Plant J. 38, 142-151.

49 Katou, S., Yoshioka, H., Kawakita, K., Rowland, O., Jones, J. D. G., Mori, H. and Doke, N. (2005) Involvement of PPS3 phosphorylated by elicitor-responsive mitogenactivated protein kinases in the regulation of plant cell death. Plant Physiol. 139, 19141926 


\section{Figure legend:}

2

\section{Figure 1: Cryptogein activates several nuclear protein kinase activities.}

Tobacco cells (Nicotiana tabacum cv. Xanthi) were treated with $100 \mathrm{nM}$ cryptogein for various times. The corresponding nuclear extracts were prepared and PK activities were analyzed by in-gel kinase assay with histone IIIS as a substrate. The phosphorylation reaction was performed in the presence of $0.5 \mathrm{mM} \mathrm{CaCl}_{2}(\mathrm{~A})$ or without $\mathrm{Ca}^{2+}$ in the medium $(2 \mathrm{mM}$ EGTA) (B); protein kinase patterns from nuclear proteins extracted using the TriReagent (lane 1) or the high salinity buffer (lane 2) protocols (C). The arrow on the right indicates the different PK activities. These experiments were repeated five times with similar results.

\section{Figure 2: Cryptogein activates a nuclear protein kinase related to MAP kinases.}

Tobacco (Nicotiana tabacum cv. Xanthi) cells were treated with $100 \mathrm{nM}$ cryptogein for various times. The corresponding nuclear extracts were prepared and PK activities were analyzed by in-gel kinase assay with MBP as a substrate, a preferred one for MAP kinase. The phosphorylation reaction was performed without $\mathrm{Ca}^{2+}$ in the medium (2 mM EGTA). This experiment is representative of three independent ones.

\section{Figure 3: The nuclear PK47 is a protein kinase closely related to SIPK.}

(A) Tobacco cells were treated with $100 \mathrm{nM}$ cryptogein for the indicated times. Cytosolic and nuclear extracts were prepared from harvested cells and proteins were separated on the same $10 \%$ polyacrylamide gel. After transfer on nitrocellulose membrane, the immunoblot was performed using antibodies directed against the N-terminal part of SIPK. The black arrow indicates the band corresponding to SIPK. Molecular mass markers are indicated on the left.

(B) Nuclear extracts containing $100 \mu \mathrm{g}$ proteins from untreated control (Cont.) or cells treated $30 \mathrm{~min}$ with $100 \mathrm{nM}$ cryptogein (Cry) were immunoprecipitated with $5 \mu \mathrm{g}$ antibodies directed against SIPK. Kinase activity of the immunocomplexes were then determined by in-gel kinase assay using histone IIIS as a substrate, in presence of $0.5 \mathrm{mM} \mathrm{CaCl}_{2}$ in the reaction buffer. The PK47-corresponding activity is indicated on the right. Molecular mass markers are indicated on the left.

\section{Figure 4: Enrichment of the nuclear PK47}

Seventy milligrams of nuclear proteins extracted from tobacco cells treated with $100 \mathrm{nM}$ cryptogein for $3 \mathrm{hrs}$ were used to enrich the PK47 activity through 2 chromatography steps. (A) Each fraction obtained after an anion exchange chromatography was analyzed by in-gel kinase assay using histone IIIS as a substrate, in the presence of $0.5 \mathrm{mM} \mathrm{CaCl}_{2}$. The arrow indicates the activity corresponding to PK47. Molecular weights are indicated on the left. (B) Each fraction after the hydrophobic chromatography was analyzed by in-gel kinase assay using histone IIIS as a substrate, in the presence of $0.5 \mathrm{mM} \mathrm{CaCl}_{2}$. The arrow indicates the activity corresponding to PK47. Molecular weights are indicated on the left.

\section{Figure 5: Identification of PK47 as SIPK.}

SIPK and Ntf4 aminoacid sequences were aligned. For Ntf4, only divergent aminoacids are indicated. The sequences of the four tryptic peptides obtained by mass spectrometry are indicated by the black lines over SIPK sequence. The aminoacid of the fourth microsequenced peptide highlighted in grey discriminate SIPK from Ntf4. Roman numerals indicate the 11 major conserved subdomains of serine/threonine protein kinases. Dotted line in subdomain VI indicates the catalytic site, the conserved residues essential for catalysis are marked with a black dot. The phosphorylated residues in the MAPK activation motif TEY are indicated with the asterisks. 
Figure 6: Integration of SIPK nuclear activity in cryptogein signalling pathway.

(A) SIPK activity was first estimated in response to cryptogein alone. Control (Cont.) and treated cells (Cry) were harvested at the indicated times and SIPK activity was analyzed in nuclear extracts by in-gel kinase assay using MBP as a substrate in absence of $\mathrm{Ca}^{2+}(2 \mathrm{mM}$ EGTA in the reaction buffer).

(B) Control or cryptogein-treated (Cry) cells were pre-treated 10 min with different inhibitors: $2 \mathrm{mM}$ gadolinium chloride $\left(\mathrm{Gd}^{3+}\right), \quad 10 \mu \mathrm{M}$ diphenylene-iodonium (DPI), $200 \mu \mathrm{M}$ glibenclamide (Gli), $500 \mu \mathrm{M}$ carboxy-PTIO (cPTIO) and $10 \mu \mathrm{M}$ cycloheximide (CHX). Cells were harvested at the indicated times, and SIPK activity was analyzed by in-gel kinase assay using MBP as a substrate in absence of $\mathrm{Ca}^{2+}$ ( 2 mM EGTA in the reaction buffer).

Figure 7: Activity of SIPK in the cytosol and nucleus in response to different stimuli.

14 Different treatments, known to activate SIPK in the cytosol, were applied to cells: $100 \mu \mathrm{g} \cdot \mathrm{mL}^{-}$

${ }^{1}$ oligogalacturonates (OGs), $250 \mu \mathrm{M}$ salicylic acid (SA), 1 and $5 \mathrm{mM}$ butyric acid and $250 \mathrm{mM}$ sorbitol. Control and treated cells were harvested at various times, and cytosolic (Cyt) and corresponding nuclear (Nuc) extracts were prepared. In-gel kinase assays were performed to analyze SIPK activity in these extracts, with MBP as a substrate in absence of $\mathrm{Ca}^{2+}$ (2 mM EGTA in the reaction buffer). 

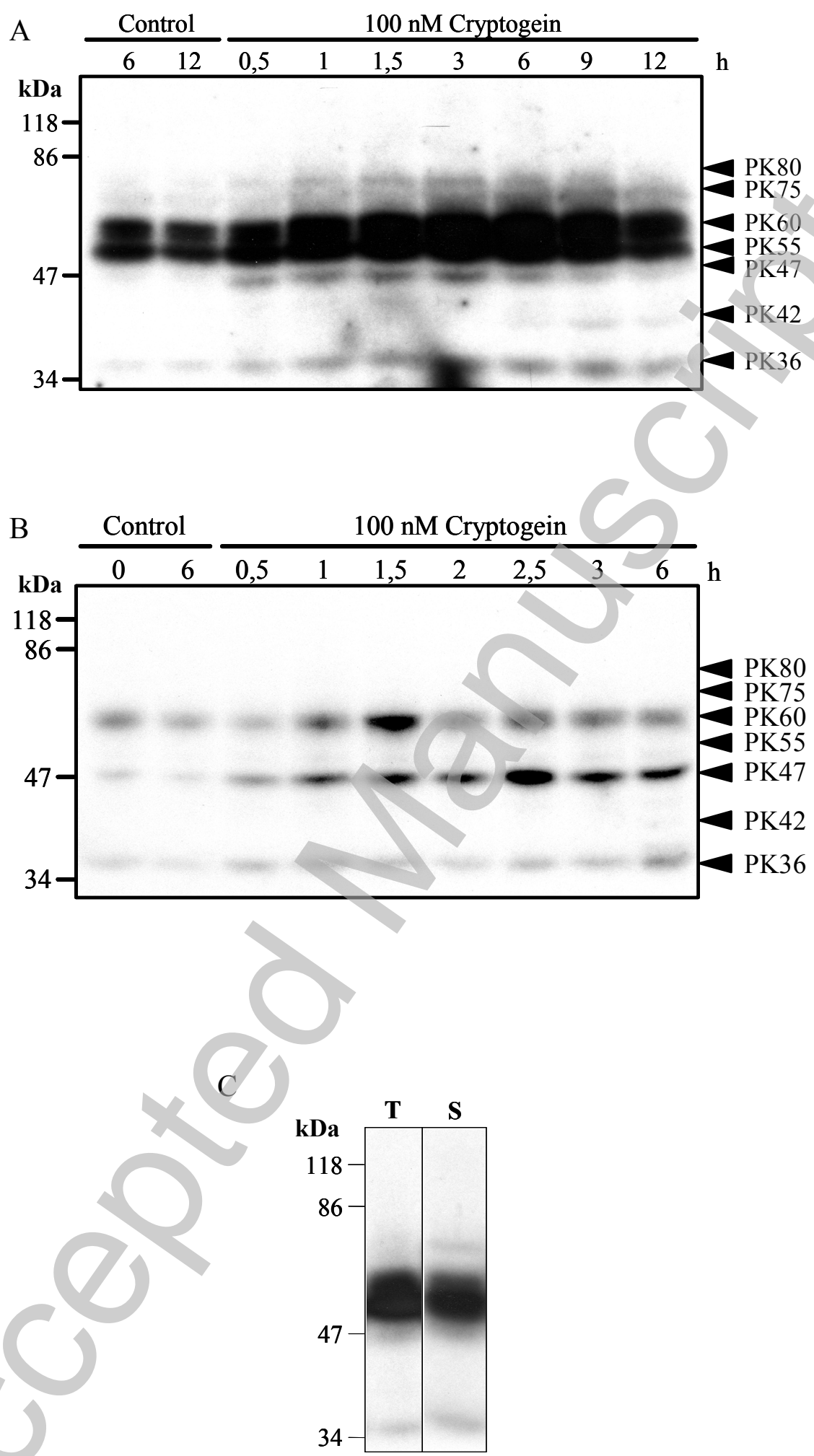

Dahan et al - Figure 1 


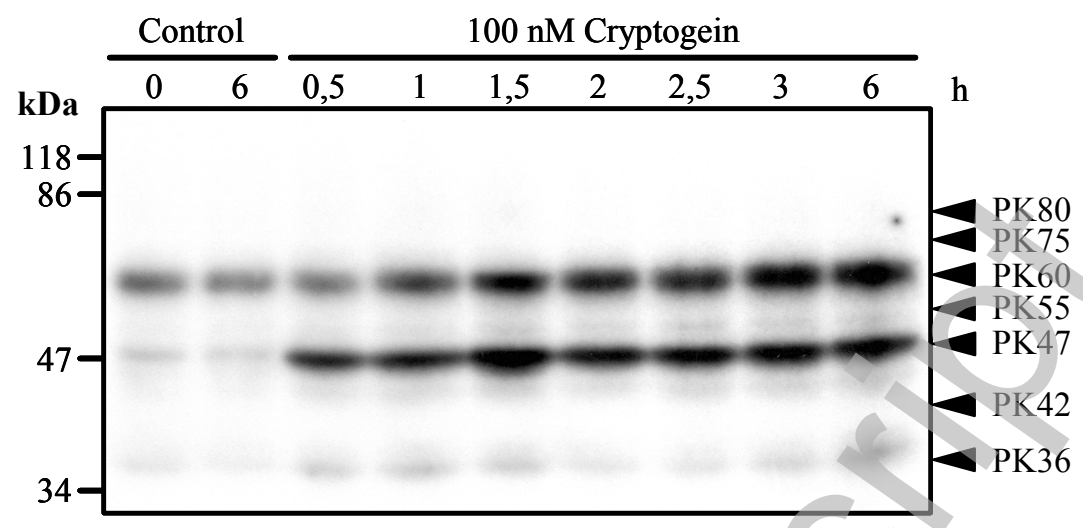

Dahan et al - Figure 2 
A

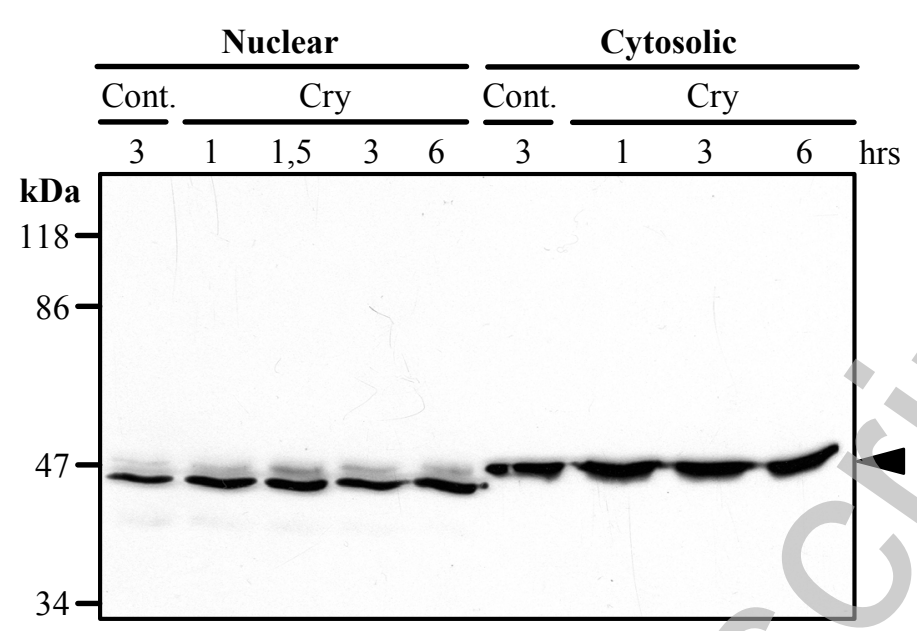

B

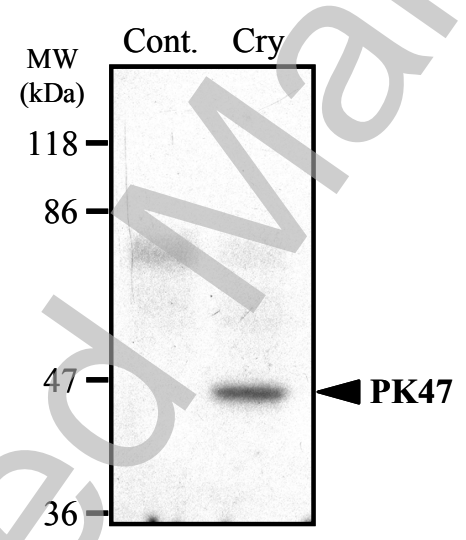

Dahan et al - Figure 3 
Biochemical Journal Immediate Publication. Published on 16 Oct 2008 as manuscript BJ20081465

A

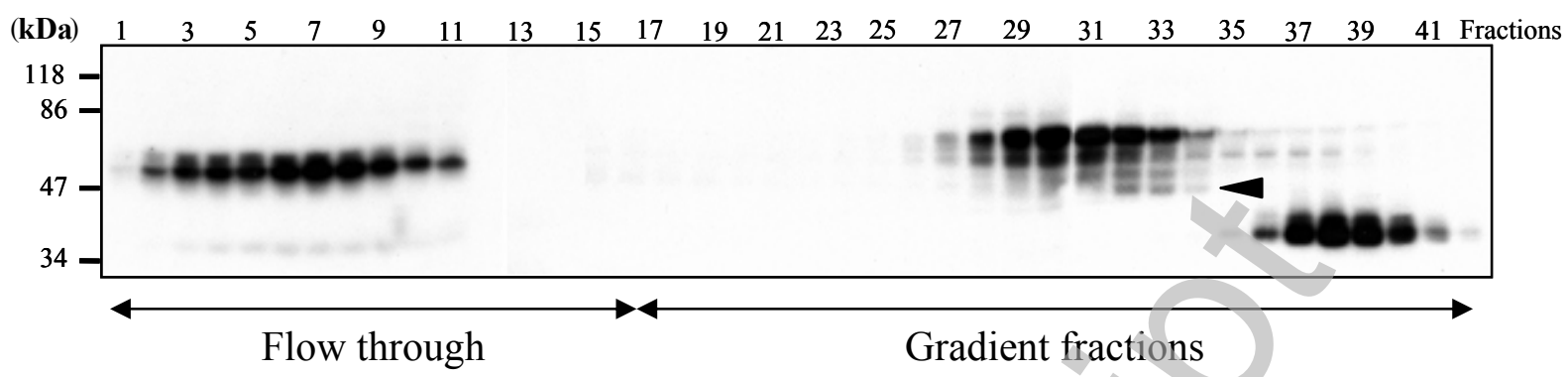

B
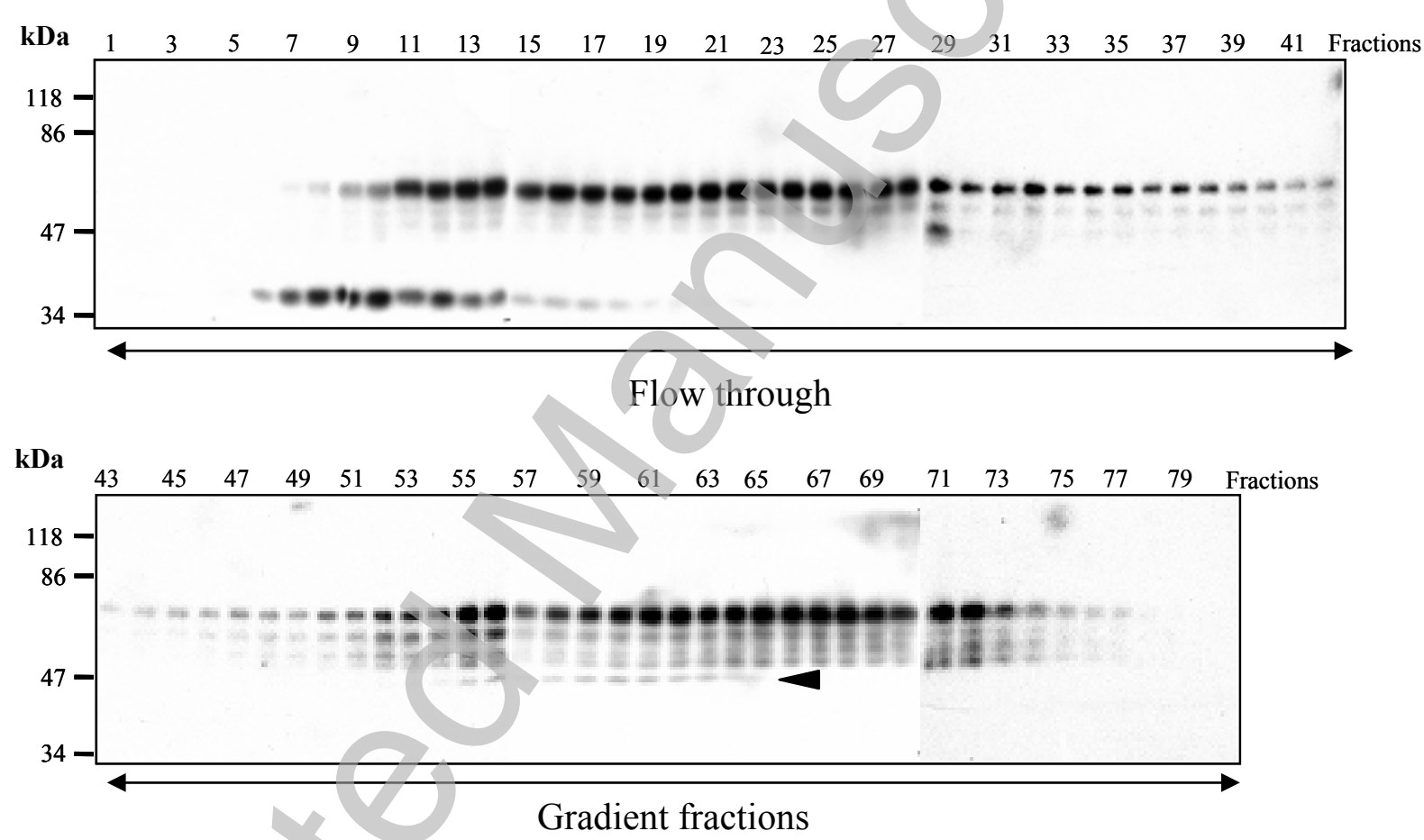

Dahan et al - Figure 4

Licenced copy. Copying is not permitted, except with prior permission and as allowed by law.

(C) 2008 The Authors Journal compilation (C) 2008 Biochemical Society 


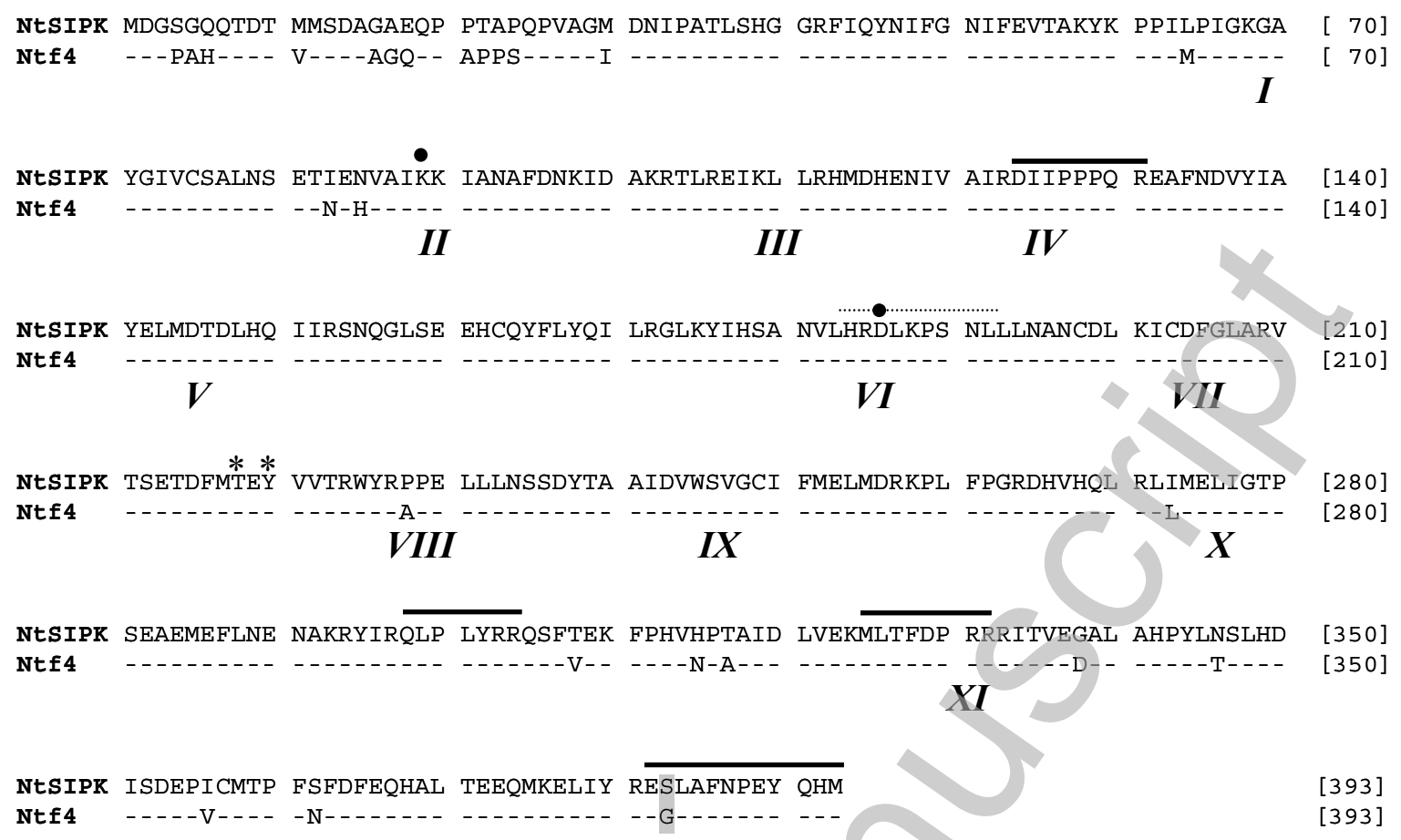

Dahan et al - Figure 5

Licenced copy. Copying is not permitted, except with prior permission and as allowed by law. (C) 2008 The Authors Journal compilation (C) 2008 Biochemical Society 

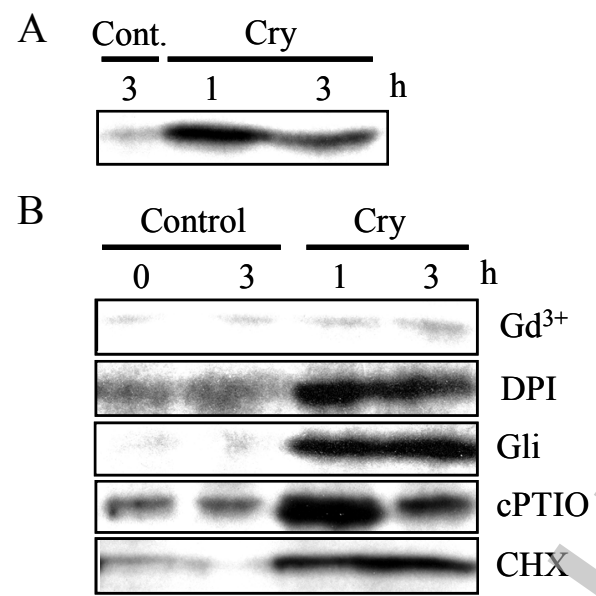

\section{Dahan et al - Figure 6}



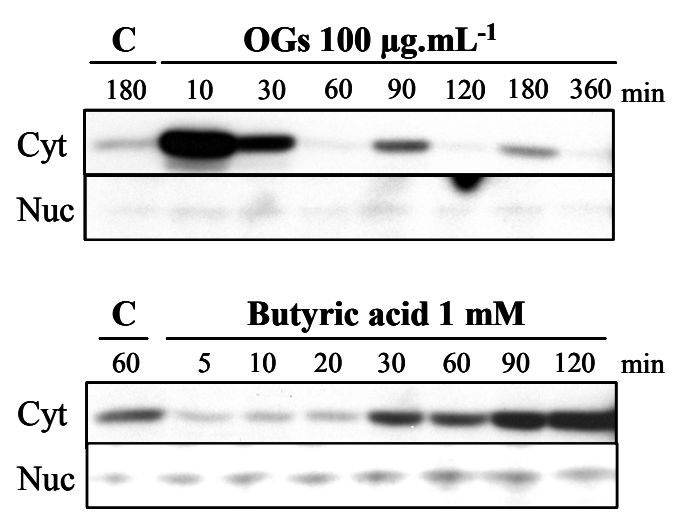
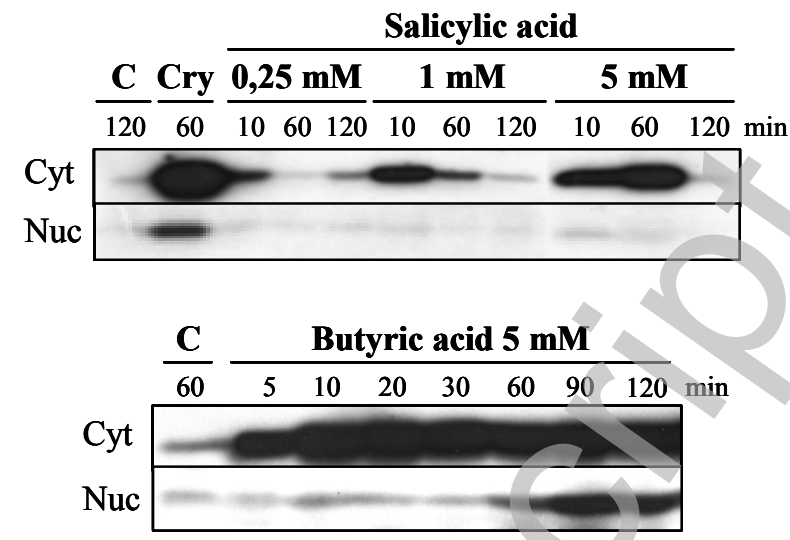

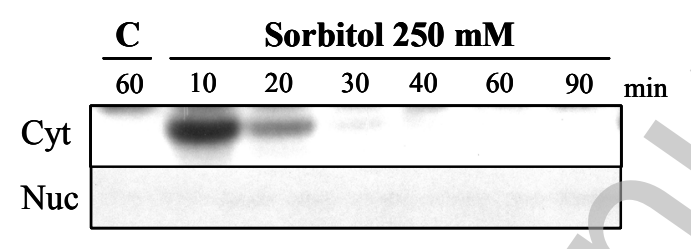

Dahan et al - Figure 7 